\title{
ASSESSMENT OF TRACE METAL CONTAMINATION BY GEOCHEMICAL NORMALISATION IN SEDIMENTS OF TWO LAGOONS: A COMPARATIVE STUDY OF THE KPESHIE AND MUNI LAGOONS, GHANA
}

\author{
M. K. Dorleku*, C. Tay, K. M. Kumi, D. K. Amoah, L. Yawson And I. O. Hodgson \\ (CSIR - Water Research Institute, P.O Box AH 38 Achimota, Accra, Ghana). \\ Corresponding author's email: mdorleku@hotmail.com.
}

\begin{abstract}
Heavy metal contamination status of bottom sediments of two lagoons was compared by the employment of Enrichment Factor (EF) analysis for Iron (Fe), Manganese (Mn), Cupper (Cu), Lead (Pb), Chromium (Cr), Nickel (Ni), Silver (Ag), Zinc ( $\mathrm{Zn})$ and Mercury (Hg). Kpeshie Lagoon recorded enrichment ( $\mathrm{EF} \geq 1$ ) for $\mathrm{Cd}, \mathrm{Pb}, \mathrm{Ag}, \mathrm{Hg}$ and $\mathrm{Zn}$, whilst Muni Lagoon recorded enrichment for $\mathrm{Cd}, \mathrm{Mn}, \mathrm{Ag}, \mathrm{Hg}$ and $\mathrm{Zn}$ as metals of anthropogenic influence. Kpeshie, situated in a highly urbanized area, has $75 \%$ spatial distribution of $\mathrm{Pb}$ enrichment. The assessment shows that $\mathrm{Ag}$ and $\mathrm{Hg}$ are the most enriched metals in the sediments of both Lagoons, reaching extremely severe levels. Only Mn showed statistically significant difference in mean concentration of metals for both Lagoons. Pearson correlation matrix indicated that $\mathrm{Pb}$ had a strong relation with $\mathrm{Ag}, \mathrm{Hg}$ and $\mathrm{Zn}(\mathrm{r}=0.956 ; \mathrm{p}<0.05)$ which is significant in Kpeshie. It also had a strong association with $\mathrm{Ag}$ and $\mathrm{Hg}$ but not with $\mathrm{Zn}(\mathrm{r}=0.240)$ in the Muni. The study clearly delineates $\mathrm{Pb}$ as a pollutant that designates the urban status of Kpeshie. Its associated metals; $\mathrm{Ag}, \mathrm{Hg}$ and $\mathrm{Zn}$ which may be coming from a common source are from industrialized zones.
\end{abstract}

Keywords: Trace Metals, Enrichment Factor, sediment, correlation matrix, lagoons

\section{Introduction}

Lagoons form part of wetland ecosystems that are made up of soils and water as well as plants and animals. The complex interaction between these components allows wetlands to specialize in the performance of certain ecological or natural functions and generate products of socio-economic importance (Larr et al, 2011). Sediments play a significant role in aquatic ecosystems and act as storage reservoirs for all kinds of pollutants which are introduced in to the ecosystem either by anthropogenic or natural processes. Natural trace metal concentrations in estuarine sediments are found at different concentrations depending on the geology of the area. Estuarine sediments also receive significant anthropogenic loads of metals from both point and non-point sources, especially in heavily industralised zones, increasing their natural background concentrations (Esen et al, 2010; Remor et al, 2018). The sediment compartment embodies the most concentrated physical pool of metals in aquatic environments (Superville et al, 2014) with more than $90 \%$ of the heavy metal load in aquatic systems said to be bound to suspended particulate matter and sediments (Calmano et al, 1993; Superville et al, 2014). These metals could be released to the overlying water column through natural and 
anthropogenic processes such as bioturbation and dredging, resulting in potential adverse health effects (Daskalakis and O'Cunnor, 1995; Long et al, 1995).

More than 50 lagoons and estuaries mark Ghana's $550 \mathrm{~km}$ coastline and provides feeding, roosting and nesting sites for thousands of migratory and resident birds; marine turtles; many species of fish; plant genetic materials for research; and a major source of income for especially poor communities. Lagoons are generally classified into 3 main types: leaky lagoons, choked lagoons, and restricted lagoons (Kjerfve, 1994). The Kpeshie lagoon located in the Greater Accra region of Ghana can be classified as a restricted lagoon in that even though it has only one channel to the sea, this channel is quite wide and allow for good water exchange, and a net transport of water to the sea (http://www.sms.si.edu/IRLSpec/ Whatsa_lagoon.htm; Kjerfve, 1994). The Kpeshie lagoon, though relatively small in size, contributed significantly to the national fish production stock in the past, however, increasing urbanization and industrialization within its catchment area has resulted in heavy pollution of the lagoon (Addo et al, 2011).

The Muni Lagoon on the other hand, is said to be located in a rural setting (Tay et al, 2010), and therefore, is expected to receive less industrial and domestic waste discharges. However, there is a gradual increasing urbanization and encroachment of its catchment area by estate developers and salt miners. Urbanization with its attendant commercialization produces pollution from metal sources. These metal contaminants may pose a high risk to the ecosystem on a large scale and hence need to be monitored at regular intervals and that natural versus anthropogenic contribution be distinguished for effective remedial actions against metal pollution.
This is effectively done by employment of geochemical normalization techniques (Nowrouzi and Pourkhabbaz, 2014), which represent actual environmental enrichment rather than the inclusion of natural geochemical background values normally reported as metal concentrations in $\mathrm{mg} / \mathrm{kg}$. Few studies were done by Tay et al, (2010) on both lagoons but not by metal normalization, and Addo et al, (2011), who studied the Kpeshie by using geochemical normalization.

Since these two Lagoons serve as feeding, migration routes, and nursery grounds of many organisms, it is important that sediment contamination by trace metals be evaluated, and that natural versus anthropogenic contribution be distinguished for effective remedial actions against metal pollution.

\section{Study area}

\section{Experimental}

The Kpeshie Lagoon (Fig. 1), lies on latitude $5^{\circ} 34^{\prime} \mathrm{N}$ to $6^{\circ} 40^{\prime} \mathrm{N}$ and longitude $0^{\circ} 00 \mathrm{E}$ to $0^{\circ} 8^{\prime} \mathrm{E}$ (Fianko et al, 2013). The Lagoon is located between the La Trade Fair (LTF) site to the west and the Teshie Military Barracks to the east. The drainage system of the lagoon has been designed to receive all storm-water from the entire catchments (Addo et al, 2011). It used to be an open Lagoon (Addo et al, 2011) but can now be described as a restricted lagoon with a narrow channel to the sea. There is another portion of the water body isolated along the La-Palm-Zenith College road. The wetland covers an area of $22 \mathrm{~km}^{2}$ and comprises sand dune, open lagoon, marshy lands and scrublands (Fianko et al, 2013). Muni Lagoon (Fig. 2), on the other hand, is a shallow saline coastal lagoon situated on the outskirts of Winneba Township, $67 \mathrm{~km}$ from the capital Accra, Lat. $5^{\circ} 19^{\prime} \mathrm{N}$, Long. $0^{\circ} 40^{\prime} \mathrm{W}$. 
It covers an area of $3 \mathrm{~km}^{2}$ and is fed by the two rivers Muni and Pratu. The Lagoon adjoins the Yenku Forest Reserve, which together with the adjacent degraded forest lands forms the traditional hunting grounds of the Efutu people. The site is mainly important for terns, but a number of waders and herons also occur in significant numbers (Ntiamoa-Baido \& Gordon, 1991). Mean monthly temperatures range from minimum of $24^{\circ} \mathrm{C}$ in July/August to maximum of $28.9^{\circ} \mathrm{C}$ in March (NtiamoaBaido \& Gordon, 1991).

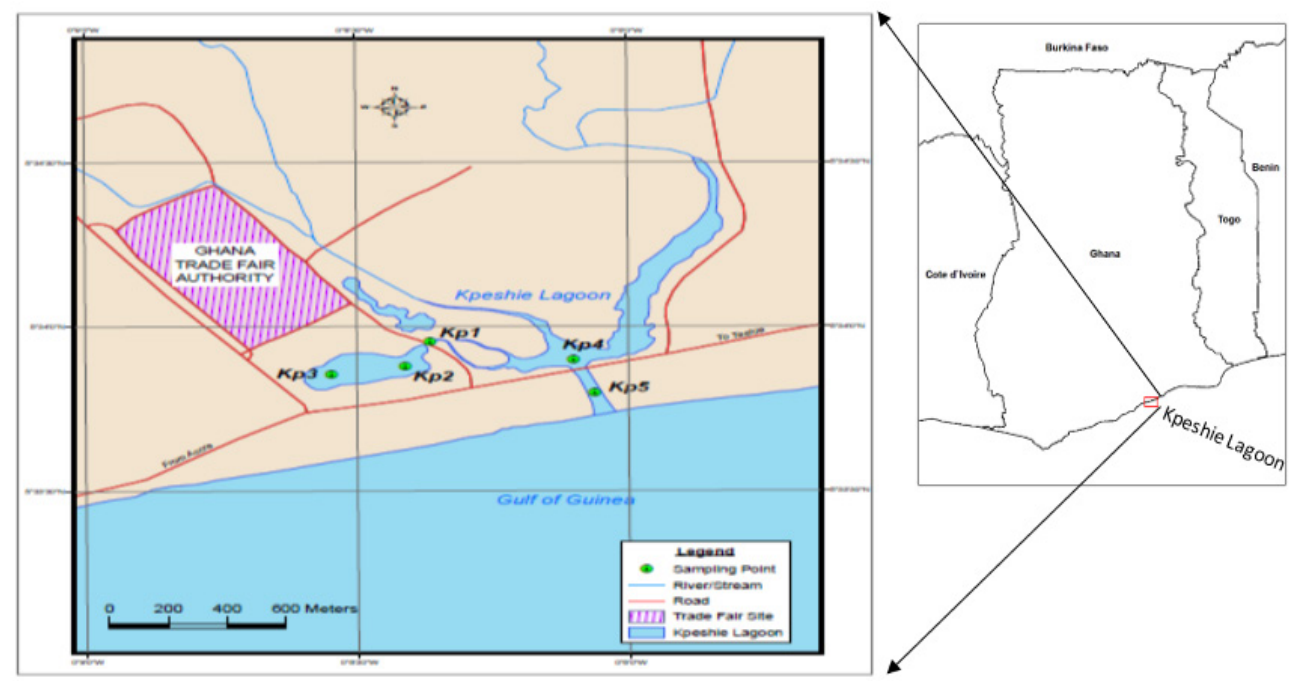

Fig. 1: Location and sampling site for Kpeshie Lagoon with Ghana map insert.

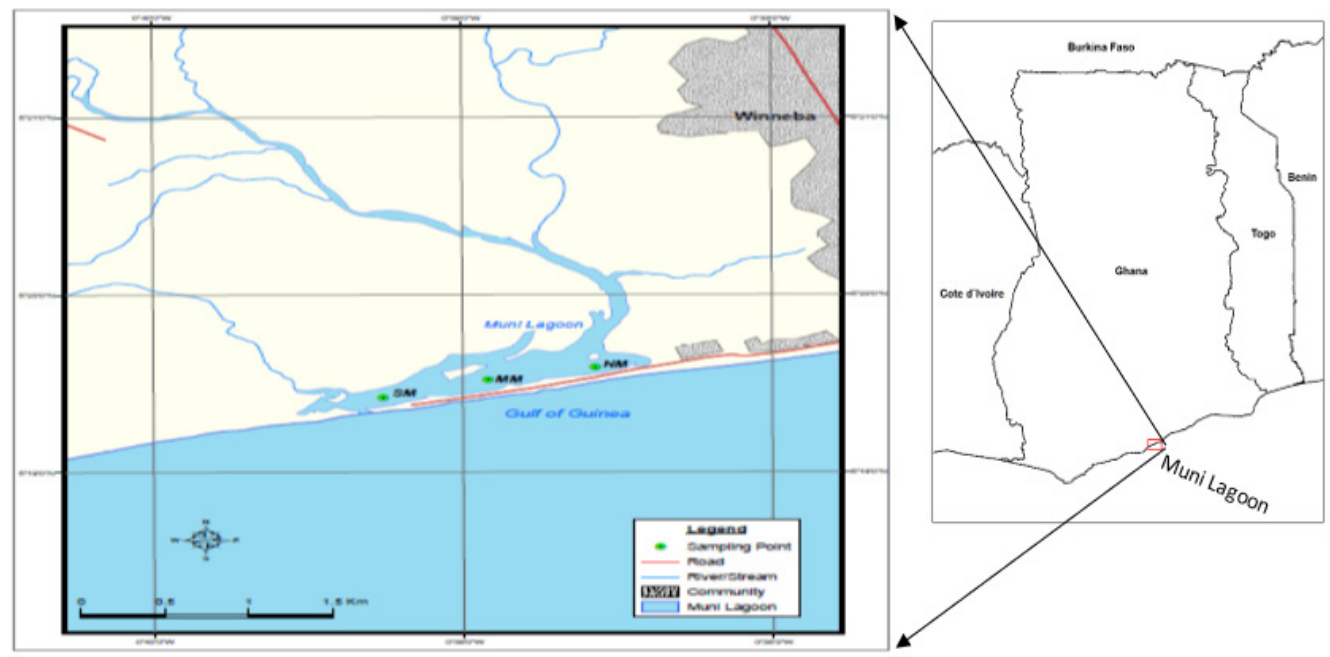

ig. 2: Location and sampling site for Muni Lagoon with Ghana map insert. 


\section{Sample collection}

Sampling was carried out bi-monthly from October 2016 up to August, 2017 for both Lagoons. The Muni lagoon had three sampling stations; NM, MM and SM whilst the Kpeshie Lagoon had five sampling stations namely; KP1, KP2, KP3, KP4 and KP5. The sampling sites were chosen based on accessibility. Water samples were collected into a $200 \mathrm{ml}$ clean plastic bottle and acidified with concentrated $\mathrm{HNO}_{3}$ for heavy metal analysis. Sediments were collected using the rod-operated 3.5 litre Ekman grab sampler. A sizeable quantity is then transferred into cleaned polyethylene bags. For Kpeshie Lagoon, sediment sample was not taken for KP1 because of accessibility at the initial stage of the study. All the samples were preserved on ice in an ice-chest and transported to the Environmental Chemistry and Sanitation Engineering Laboratories of the CSIR-Water Research Institute and kept in the refrigerator at $<4^{\circ} \mathrm{C}$ until analysed.

\section{Sediment digestion}

The sediments were air-dried, grounded, homogenized and sieved using $63 \mu \mathrm{m}$ aperture sieve. This is done because trace elements are disproportionately associated with different particle sizes, the particle-size distribution of a bulk sample can greatly influence metal concentrations of that sample (Salomons \& Forstner, 1984).About $0.30 \mathrm{~g}$ of the driedhomogenized sediment sample was weighed carefully into Teflon tubes, $8 \mathrm{mls}$ and $2 \mathrm{mls}$ of $65 \% \mathrm{HNO}_{3}$ and $\mathrm{HF}$ were respectively added. The samples were digested using Milestone Microwave Digestion System as directed by Standard Methods for the Examination of Water and Wastewater - (APHA, 2017) and digested using US EPA method 3052 (Kington and Walter, 1992). The samples were then taken out and top up with deionised water to $50 \mathrm{mls}$ and analyzed for metals.

\section{Metal analysis}

Metals were determined for the sediments by Atomic Absorption Spectrophotometer (AAS), Agilent 240F Series. AAS-flame technique was used for $\mathrm{Fe}, \mathrm{Mn}, \mathrm{Cu}, \mathrm{Pb}, \mathrm{Cr}, \mathrm{Ni}$, $\mathrm{Ag}$ and $\mathrm{Zn}$ whilst AAS-Cold vapour technique was used for $\mathrm{Hg}$. The sediment results were then converted to $\mathrm{mg} / \mathrm{kg}$ before being geochemically normalised.

\section{Geochemical normalisation}

Enrichment Factor(EF) is one of environmental parameters used in assessing pollution levels in sediments and environmental impact of metals. It is a relatively simple and easy tool for assessing the enrichment degree and comparing the contamination of different environmental media (Benhaddya \& Hadjel, 2013). The EF is a normalisation method proposed by Simex \& Helz (1981) to assess the concentration of the metals. It normalizes metal concentration as a ratio to another constituent of the sediments. The geochemical normalization was obtained using $\mathrm{Fe}$ as the reference element for the following reasons (Daskalakis \& O'Connor, 1995): (1) $\mathrm{Fe}$ is associated with fine solid surfaces; (2) its geochemistry is similar to that of many trace metals; and (3) its natural sediment concentration tends to be uniform. The EF is defined by the Equation (1):

$$
\frac{\mathrm{EF}=(\mathrm{Me} / \mathrm{Fe})_{\text {sample }}}{(\mathrm{Me} / \mathrm{Fe})_{\text {aveg.shale value }}}
$$

Where, $(\mathrm{Me} / \mathrm{Fe})_{\text {sample }}$ is the ratio of metal and $\mathrm{Fe}$ concentrations in the sample, and $(\mathrm{Me} /$ $\mathrm{Fe})_{\text {aveg.shalevalue }}$ is the ratio of metal and $\mathrm{Fe}$ concentrations of the average shale values. 
The world average shale and the world average soil are among the materials often used to provide background metal levels. Hence the background concentrations of the metals in the average shale as provided by Turekian \& Wedepohl (1961) are used in this study.

EF values were interpreted as suggested by Birch (2003) where EF $<1$ indicates no enrichment, $<3$ is minor; $3-5$ is moderate; $5-10$ is moderately severe; $10-25$ is severe; $25-50$ is very severe; and $>50$ is extremely severe. Enrichment factor (EF) for $\mathrm{Fe}$ was not calculated because $\mathrm{Fe}$ is the normalizing element.

\section{Quality control}

All laboratory wares used were washed with phosphate-free soap, double rinsed with distilled water and left in $10 \% \mathrm{HNO}_{3}$ for $24 \mathrm{hrs}$. They were removed, rinsed again with double distilled water and dried. Certified Reference Material (CRM), IAEA-356 marine sediment was used and taken through the same process as the sediment samples as a precision check any time samples are being analyzed. Recovery and accuracy for certified and measured values were compared (Table 1).

TABLE 1

Measured and certified concentrations in $\mathrm{mg} / \mathrm{kg}$ of CRM (IAEA - 356), $(n=4)$.

\begin{tabular}{cccc}
\hline Element & Measured & Certified & \% Recovery \\
\hline $\mathbf{A g}$ & $7.48 \pm 1.40$ & 8.41 & 88.9 \\
$\mathbf{F e}$ & $25,372 \pm 924$ & 24,100 & 105.3 \\
$\mathbf{M n}$ & $322 \pm 18$ & 312 & 103.2 \\
$\mathbf{C d}$ & $3.56 \pm 0.95$ & 4.47 & 79.6 \\
$\mathbf{C u}$ & $329 \pm 14$ & 365 & 90.1 \\
$\mathbf{C r}$ & $47.6 \pm 8.1$ & 69.8 & 68.2 \\
$\mathbf{N i}$ & $41.3 \pm 6.11$ & 36.9 & 111.9 \\
$\mathbf{P b}$ & $357 \pm 2.8$ & 347 & 102.9 \\
$\mathbf{H g}$ & $7.77 \pm 0.32$ & 7.62 & 102.0 \\
$\mathbf{Z n}$ & $806 \pm 18.1$ & 977 & 82.5 \\
\hline
\end{tabular}

\section{Results and Discussion}

TABLE 2

Mean concentration of bottom sediments in $\mathrm{mg} / \mathrm{kg}$ for Muni lagoon.

\begin{tabular}{ccccccccccc}
\hline ID & Fe & Mn & $\mathbf{C u}$ & $\mathbf{N i}$ & $\mathbf{C r}$ & $\mathbf{C d}$ & $\mathbf{P b}$ & $\mathbf{A g}$ & $\mathbf{H g}$ & $\mathbf{Z n}$ \\
\hline $\mathbf{N M}$ & 12258 & 225.0 & 6.15 & 15.1 & 12.2 & 0.593 & 3.85 & 1.90 & 1.93 & 31.4 \\
$\mathbf{M M}$ & 12279 & 332.0 & 6.46 & 14.2 & 7.70 & 0.552 & 7.23 & 1.17 & 2.44 & 49.9 \\
$\mathbf{S M}$ & 13525 & 309.4 & 10.2 & 21.6 & 17.2 & 0.568 & 4.68 & 1.65 & 1.96 & 68.1 \\
\hline
\end{tabular}


TABLE 3

Mean concentration of bottom sediments in $\mathrm{mg} / \mathrm{kg}$ for Kpeshie lagoon.

\begin{tabular}{ccccccccccc}
\hline ID & Fe & Mn & $\mathbf{C u}$ & $\mathbf{N i}$ & $\mathbf{C r}$ & $\mathbf{C d}$ & $\mathbf{P b}$ & $\mathbf{A g}$ & $\mathbf{H g}$ & $\mathbf{Z n}$ \\
\hline KP2 & 7311 & 80.2 & 6.35 & $\mathbf{9 . 3 4}$ & 4.37 & 0.569 & 8.19 & 3.05 & 3.20 & 40.9 \\
KP3 & 11291 & 158.6 & 8.74 & $\mathbf{1 1 . 5 6}$ & 22.8 & 0.799 & 17.6 & 5.51 & 1.68 & 49.6 \\
KP4 & 27224 & 139.5 & 17.7 & 7.00 & 23.7 & $<0.200$ & 0.511 & 1.81 & 5.79 & 27.2 \\
KP5 & 16076 & 119.8 & 6.53 & 8.38 & 10.7 & 0.337 & 8.88 & 1.11 & 1.90 & 35.0 \\
\hline
\end{tabular}

Mean Fe concentration ranged between 12258 and $13525 \mathrm{mg} / \mathrm{kg}$ dry weight (dw) for Muni lagoon whilst Kpeshie lagoon recorded a mean range between 7311 and $27224 \mathrm{mg} /$ $\mathrm{kg} \mathrm{dw}$. The result obtained for Kpeshie was highly variable $15476 \mathrm{mg} / \mathrm{kg} \pm 8613$ (Table 5), largely influenced by station KP2. The average shale value for $\mathrm{Fe}$ is 47200 which is far higher than what was obtained for the two Lagoons, indicating non-anthropogenic input in the sediment of both Lagoons.

This suggests that the presence of $\mathrm{Fe}$ in the sediments is principally from natural sources which came from the earth crust. The use of T-test with unequal variance recorded no statistical significant difference between mean concentrations of $\mathrm{Fe}$ for Muni and Kpeshie $(p=0.565) p>0.05$ at the $95 \%$ confidence level. Mn for Muni ranged between 225 and $332 \mathrm{mg} / \mathrm{kg}$ dw whilst that of Kpeshie Lagoon ranged between 80.2 and $158.6 \mathrm{mg} / \mathrm{kg}$ dw. Consequently, the Enrichment Factor (EF) for Muni ranged between 1.02 and 1.50 with a mean of 1.26, higher than that of Kpeshie which ranged between 0.285 and 0.780 with a mean of 0.522 even though the latter is situated in a highly urbanised location. The values in all the stations in Muni showed minor enrichment $(\mathrm{EF} \geq 1)$ whilst that of Kpeshie recorded no enrichment (Table 6), clearly indicating that the presence of $\mathrm{Mn}$ in sediments of Kpeshie Lagoon is principally from natural sources.
The minor enrichment in sediments of Muni Lagoon might be as a result of using part of the Lagoon as a receptacle for refuse by the nearby fishing community, as manganese can be released into water bodies as leachate from landfills (Francis \& White, 1987), thereby, enriching the water with manganese and subsequently settling in bottom sediments. There was a significant difference between the mean concentrations of Muni and Kpeshie $(\mathrm{p}=0.019), \mathrm{p}<0.05$, further indicating that Muni was anthropogenically enriched. $\mathrm{Cu}$ for Muni recorded a mean range of 6.15 and 10.20 $\mathrm{mg} / \mathrm{kg}$ whilst that of Kpeshie recorded values between 6.35 and $17.7 \mathrm{mg} / \mathrm{kg}$. The Threshold Effect Concentration (TEC) (which is a screening value, below which concentrations of contaminants have not been shown to cause an effect on aquatic organisms) for sediments in surface waters set by US Environmental Protection Agency (USEPA) for $\mathrm{Cu}$ is 31.6 $\mathrm{mg} / \mathrm{kg}$. The mean enrichment factor $(<1.0)$ for Muni and Kpeshie are 0.628 and 0.666 respectively, suggesting natural geochemical presence of $\mathrm{Cu}$ in both sediments of the Lagoons rather than anthropogenic contribution. There was no significant difference between the concentrations of the two Lagoons for $\mathrm{Cu},(\mathrm{p}=$ 0.492). The mean Ni concentration range for Muni and Kpeshie were between 14.2 and 21.6 $\mathrm{mg} / \mathrm{kg}$ and 7.00 and $11.56 \mathrm{mg} / \mathrm{kg}$ respectively, with a p-value of 0.060 . The TEC value set by 
USEPA for Ni is $22.7 \mathrm{mg} / \mathrm{kg}$. The EF for Muni and Kpeshie are 0.929 and 0.407 respectively, indicating non-anthropogenic influence. However, station SM for Muni recorded a value of 1.11(Table 6) which is indicative of minor enrichment from anthropogenic influence. This station is very close to a fishing community; therefore, their activities might have contributed to this enrichment, possibly from Cd-Ni base batteries (Hutton et al., 1987). These values were relatively lower than similar work by Nowrouzi and Pourkhabbaz (2014) in the Persian Gulf who recorded a mean EF of 1.62 for Ni. Cr recorded mean range between 7.70 and $17.2 \mathrm{mg} / \mathrm{kg} \mathrm{dw}$ for Muni and between 4.37 and $23.7 \mathrm{mg} / \mathrm{kg} \mathrm{dw}$ for Kpeshie Lagoon. Muni Lagoon recorded a mean EF of 0.512 against 0.522 for Kpeshie Lagoon, both showing no enrichment, even though station KP3 for Kpeshie shows minor enrichment.

This station might have benefited from direct deposition of $\mathrm{Cr}$ related materials from a close by vehicle mechanic workshop. $\mathrm{Cd}$ recorded a mean range between 0.552 and $0.593 \mathrm{mg} / \mathrm{kg}$ for Muni and between $<0.200$ and $0.799 \mathrm{mg} / \mathrm{kg}$ for Kpeshie. Addo et al (2011), recorded a range between 0.20 and $2.8 \mathrm{mg} / \mathrm{kg}$ for Kpeshie Lagoon. Station KP3 of Kpeshie which recorded $0.799 \mathrm{mg} / \mathrm{kg}$ is higher than the Threshold Effect Concentration of 0.600 $\mathrm{mg} / \mathrm{kg}$. There was however, no significant difference in mean concentration between the two Lagoons $(\mathrm{p}=0.526)$. The mean $\mathrm{Cd}$ EF for Muni and Kpeshie were 7.08 and 5.77 respectively indicating moderately severe enrichment for both Lagoons. These values were however lower than the value 16.91, obtained by Nowrouzi \& Pourkhabbaz (2014) in the Persian Gulf. However, station KP4 of Kpeshie which recorded an EF factor of 0.578 showed no enrichment for that station. $\mathrm{Cd}$ enrichment is therefore from anthropogenic sources for both Lagoons, possibly from industrial effluents. Station KP4 receives freshwater from a community nearby, leading to the dilution of sediment concentration. This is further shown in the EF values for this station in all metals that exhibit some spatial enrichment (Table 6). The overall mean $\mathrm{Pb}$ value recorded for Muni was $5.25 \mathrm{mg} / \mathrm{kg}$ as against $8.80 \mathrm{mg} / \mathrm{kg}$ for Kpeshie. However, Addo et al. (2011), recorded a range between 0.50 and $27.05 \mathrm{mg} / \mathrm{kg}$ for Kpeshie lagoon. The TEC for $\mathrm{Pb}$ in sediments as given by USEPA is $35 \mathrm{mg} / \mathrm{kg}$. The EF for Muni and Kpeshie were respectively 0.977 and 1.34 indicating a minor enrichment of $\mathrm{Pb}$ in the Kpeshie Lagoon. There was however, a minor enrichment recorded at station MM of the Muni Lagoon, whilst all the stations except KP4 for Kpeshie were indicative of enrichment of $\mathrm{Pb}$. This enrichment might have been contributed by a series of artisanal related workshops dotted around the catchment area of the Lagoon.

There was no significant difference between the concentrations of the two Lagoons $(\mathrm{p}=0.392)$. Silver $(\mathrm{Ag})$ and Mercury $(\mathrm{Hg})$ were the two metals that indicated extremely severe enrichment in this study. Ag for Muni ranged between 1.17 and $1.90 \mathrm{mg} / \mathrm{kg}$ whilst that of Kpeshie ranged between 1.11 and 5.51 $\mathrm{mg} / \mathrm{kg}$. Both Lagoons are highly enriched with Ag with Muni recording Enrichment Factor (EF) of 73.1 and Kpeshie an EF factor of 109, indicating very severe enrichment. Silver is a rare but naturally occurring metal, often found deposited as a mineral ore in association with other elements; its bacteriostatic properties made it to be used in filters and other equipment to purify swimming pool water and drinkingwater and in the processing of foods, drugs, and beverages (ATSDR, 1990). Silver adsorbs to manganese dioxide, ferric compounds, and 
clay minerals, leading to silver deposition into sediments (US EPA, 1980). Silver sorbs readily to phytoplankton and to suspended sediments, especially in the marine environment because of affinity of silver for the chloride ion (Sanders et al., 1991). This might have accounted for the $\mathrm{Ag}$ concentrations in the sediments of the two coastal Lagoons. Kpeshie which recorded a higher EF value for Ag was influenced by station KP3 which has a mechanic shop close by. The overall mean mercury $(\mathrm{Hg})$ for Muni and Kpeshie Lagoons were 2.11 and 3.14 $\mathrm{mg} / \mathrm{kg}$ respectively. These values exceed the Probable Effect Limit (PEL) (a value above which toxic effects are likely to occur, and compounds that exceed it are more probably elevated to toxic levels) of $0.486 \mathrm{mg} / \mathrm{kg}$ set by USEPA. The EF values for Muni and Kpeshie were 19.6 and 24.0 respectively, indicating severe enrichment for both Lagoons.
However, spatial distribution shows extremely severe enrichment in the case of station KP2 for Kpeshie Lagoon. While local sources may contribute significantly to inorganic $\mathrm{Hg}$ deposition in highly industralised regions (Jensen \& Invefeldt, 1994), as in the case of Kpeshie lagoon, $\mathrm{Hg}$ from the global pool contributes more significantly to the deposition in more remote non-industrialized regions (Guentzel et al, 2001), as in the case of Muni Lagoon. Concentration of $\mathrm{Zn}$ ranged between 31.4 and $68.1 \mathrm{mg} / \mathrm{kg}$ for Muni lagoon, whilst Kpeshie lagoon recorded values between 27.2 and $49.6 \mathrm{mg} / \mathrm{kg}$. These values are far below the PEL value of $315 \mathrm{mg} / \mathrm{kg}$ for which aquatic life could be affected. The EF values are 1.95 and 1.23 for Muni and Kpeshie respectively, indicating minor enrichment. The highest spatial enrichment however occurred at station KP2 of the Kpeshie lagoon.

TABLE 4

Minimum, maximum, mean, in $\mathrm{mg} / \mathrm{kg}$ and EF values for Muni lgoon.

\begin{tabular}{ccccccc}
\hline Element & Min & Max & Mean & Stdev & Av.shale value & EF \\
\hline Fe & 12258 & 13525 & 12688 & 725.5 & 47200 & - \\
Mn & 225 & 332 & 288.8 & 56.4 & 850 & 1.26 \\
$\mathbf{C u}$ & 6.15 & 10.2 & 7.60 & 2.2 & 45 & 0.628 \\
$\mathbf{N i}$ & 14.2 & 21.6 & 17.0 & 4.06 & 68 & 0.929 \\
$\mathbf{C r}$ & 7.7 & 17.2 & 12.4 & 4.77 & 90 & 0.512 \\
$\mathbf{C d}$ & 0.552 & 0.593 & 0.571 & 0.02 & 0.3 & 7.08 \\
$\mathbf{P b}$ & 3.85 & 7.23 & 5.25 & 1.76 & 20 & 0.977 \\
$\mathbf{A g}$ & 1.17 & 1.90 & 1.57 & 0.37 & 0.08 & 73.1 \\
$\mathbf{H g}$ & 1.93 & 2.44 & 2.11 & 0.29 & 0.4 & 19.6 \\
$\mathbf{Z n}$ & 31.4 & 68.1 & 49.8 & 18.34 & 95 & 1.95 \\
\hline
\end{tabular}


TABLE 5

Minimum, maximum, mean, in $\mathrm{mg} / \mathrm{kg}$ and EF values for Kpeshie lagoon.

\begin{tabular}{ccccccc}
\hline Element & Min & Max & Mean & Stdev & Av.shale value & EF \\
\hline $\mathbf{F e}$ & 7311 & 27224 & $\mathbf{1 5 4 7 6}$ & 8613 & 47200 & - \\
$\mathbf{M n}$ & 80.2 & 158.6 & $\mathbf{1 2 4 . 5}$ & 33.50 & 850 & 0.447 \\
$\mathbf{C u}$ & 6.35 & 17.7 & $\mathbf{9 . 8 2}$ & 5.34 & 45 & 0.666 \\
$\mathbf{N i}$ & 7.00 & 11.56 & $\mathbf{9 . 0 7}$ & 1.92 & 68 & 0.407 \\
$\mathbf{C r}$ & 4.37 & 23.7 & $\mathbf{1 5 . 4 0}$ & 9.44 & 90 & 0.522 \\
$\mathbf{C d}$ & $<0.2$ & 0.799 & $\mathbf{0 . 3 3 7}$ & 0.23 & 0.3 & 5.77 \\
$\mathbf{P b}$ & 0.511 & 17.6 & $\mathbf{8 . 8 0}$ & 7.00 & 20 & 1.34 \\
$\mathbf{A g}$ & 1.11 & 5.51 & $\mathbf{2 . 8 7}$ & 1.93 & 0.08 & 109 \\
$\mathbf{H g}$ & 1.68 & 5.79 & $\mathbf{3 . 1 4}$ & 1.89 & 0.4 & 24.0 \\
$\mathbf{Z n}$ & 27.2 & 49.6 & $\mathbf{3 8 . 2}$ & 9.44 & 95 & 1.23 \\
\hline
\end{tabular}

TABLE 6

Enrichment Factors of both Muni and Kpeshie lagoons for each station.

\begin{tabular}{cccccccccc}
\hline MUNI & $\mathbf{M n}$ & $\mathbf{C u}$ & $\mathbf{N i}$ & $\mathbf{C r}$ & $\mathbf{C d}$ & $\mathbf{P b}$ & $\mathbf{A g}$ & $\mathbf{H g}$ & $\mathbf{Z n}$ \\
\hline NM & 1.02 & 0.526 & 0.853 & 0.522 & 7.608 & 0.740 & 91.2 & 18.6 & 1.27 \\
MM & 1.50 & 0.552 & 0.805 & 0.329 & 7.073 & 1.390 & 56.4 & 23.5 & 2.02 \\
SM & 1.27 & 0.789 & 1.111 & 0.669 & 6.602 & 0.816 & 71.9 & 17.1 & 2.50 \\
& & & & & & & & \\
\hline KPESHIE & & & & & & & & & \\
\hline KP2 & 0.610 & 0.912 & 0.887 & 0.313 & 12.2 & 2.64 & 246 & 51.7 & 2.78 \\
KP3 & 0.780 & 0.812 & 0.711 & 1.06 & 11.1 & 3.68 & 288 & 17.5 & 2.18 \\
KP4 & 0.285 & 0.681 & 0.178 & 0.457 & 0.578 & 0.044 & 39.2 & 25.1 & 0.50 \\
KP5 & 0.414 & 0.426 & 0.362 & 0.350 & 3.30 & 1.30 & 40.8 & 14.0 & 1.08 \\
\hline
\end{tabular}


Ag for Kpeshie

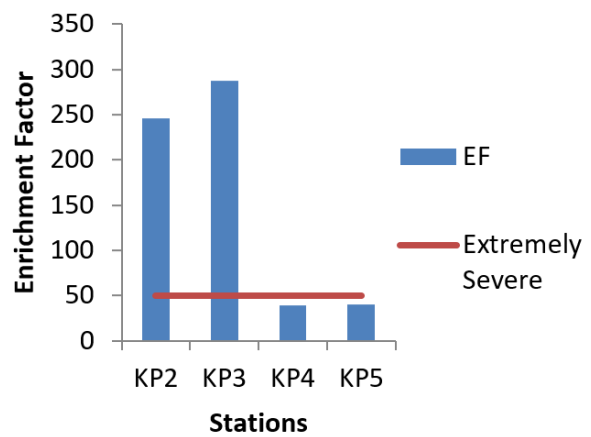

Hg for Kpeshie

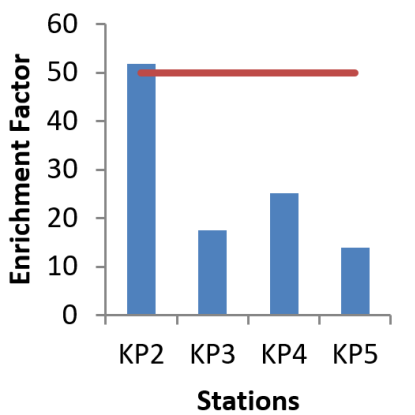

Ag for Muni

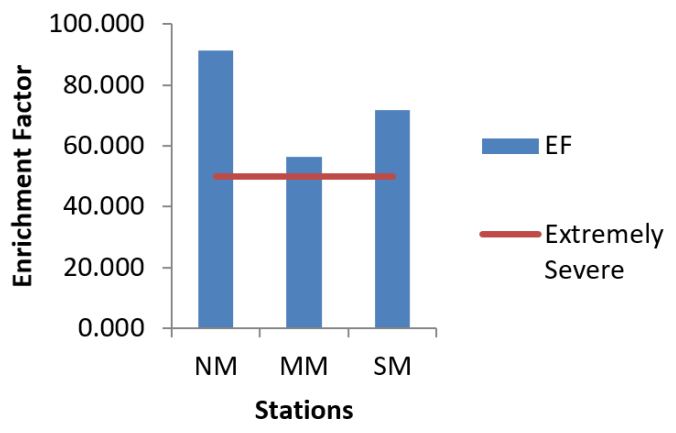

Hg for Muni

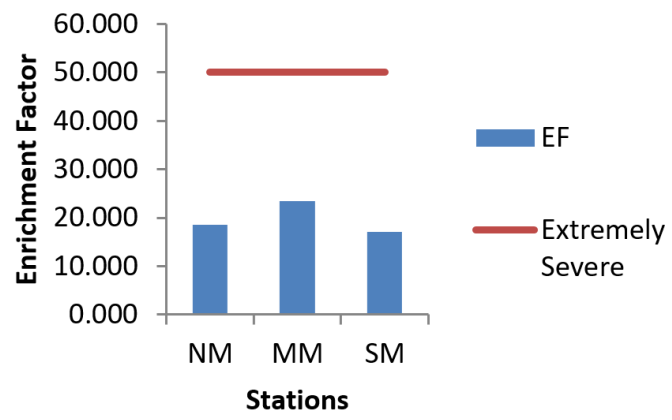

Fig 3: Spatial distribution of $\mathrm{Ag}$ and $\mathrm{Hg}$, showing extremely severe enrichment of sediments in the lagoons.

TABLE 7

Pearson's correlation coefficient between metals for Kpeshie Lagoon.

\begin{tabular}{lllllllllll}
\hline & $\mathrm{Fe}$ & $\mathrm{Mn}$ & $\mathrm{Cu}$ & $\mathrm{Ni}$ & $\mathrm{Cr}$ & $\mathrm{Cd}$ & $\mathrm{Pb}$ & $\mathrm{Ag}$ & $\mathrm{Hg}$ & $\mathrm{Zn}$ \\
\hline $\mathrm{Fe}$ & 1 & & & & & & & & & \\
$\mathrm{Mn}$ & 0.453 & 1 & & & & & & & & \\
$\mathrm{Cu}$ & 0.892 & 0.465 & 1 & & & & & & & \\
$\mathrm{Ni}$ & -0.754 & 0.234 & -0.573 & 1 & & & & & \\
$\mathrm{Cr}$ & 0.63 & 0.935 & 0.732 & 0.028 & 1 & & & & \\
$\mathrm{Cd}$ & -0.798 & 0.129 & -0.564 & $0.987^{*}$ & -0.037 & 1 & & & \\
$\mathrm{~Pb}$ & -0.715 & 0.288 & -0.65 & $0.966^{*}$ & 0.014 & 0.916 & 1 & & & \\
$\mathrm{Ag}$ & -0.521 & 0.383 & -0.194 & 0.901 & 0.311 & 0.92 & 0.783 & 1 & & \\
$\mathrm{Hg}$ & 0.738 & -0.036 & 0.868 & -0.759 & 0.306 & -0.686 & -0.883 & -0.408 & 1 & \\
$\mathrm{Zn}$ & -0.822 & 0.125 & -0.643 & $0.994^{* *}$ & -0.081 & $0.991^{* *}$ & $0.956^{*}$ & 0.872 & -0.777 & 1 \\
\hline
\end{tabular}

Note: * significant at $p<0.05 ; * *$ significant at $p<0.01$ 
TABLE 8

Pearson's correlation coefficient between metals for Muni Lagoon.

\begin{tabular}{|c|c|c|c|c|c|c|c|c|c|c|}
\hline & $\mathrm{Fe}$ & $\mathrm{Mn}$ & $\mathrm{Cu}$ & $\mathrm{Ni}$ & $\mathrm{Cr}$ & $\mathrm{Cd}$ & $\mathrm{Pb}$ & $\mathrm{Ag}$ & $\mathrm{Hg}$ & $\mathrm{Zn}$ \\
\hline $\mathrm{Fe}$ & 1 & & & & & & & & & \\
\hline $\mathrm{Mn}$ & 0.33 & 1 & & & & & & & & \\
\hline $\mathrm{Cu}$ & 0.999* & 0.381 & 1 & & & & & & & \\
\hline $\mathrm{Ni}$ & 0.992 & 0.209 & 0.984 & 1 & & & & & & \\
\hline $\mathrm{Cr}$ & 0.874 & -0.171 & 0.846 & 0.928 & 1 & & & & & \\
\hline $\mathrm{Cd}$ & -0.14 & -0.981 & -0.194 & -0.014 & 0.359 & 1 & & & & \\
\hline $\mathrm{Pb}$ & -0.268 & 0.821 & -0.215 & -0.387 & -0.703 & -0.915 & 1 & & & \\
\hline $\mathrm{Ag}$ & 0.165 & -0.877 & 0.111 & 0.288 & 0.623 & 0.954 & -0.994 & 1 & & \\
\hline $\mathrm{Hg}$ & -0.441 & 0.702 & -0.392 & -0.505 & -0.822 & -0.827 & 0.983 & -0.958 & 1 & \\
\hline $\mathrm{Zn}$ & 0.871 & 0.751 & 0.896 & 0.802 & 0.522 & -0.609 & 0.24 & -0.341 & 0.057 & 1 \\
\hline
\end{tabular}

Note: * significant at $p<0.05$

\section{Correlation matrix}

Pearson's correlation coefficient was used to ascertain the sources, the spatial distribution and inter-relationship that exist between metals in the wetlands (Tables 7\&8). Elemental association may signify that each paired elements has identical source or common sink in the stream sediments (Fianko et al, 2013). There was a strong positive correlation between $\mathrm{Fe}$ and $\mathrm{Cu}(\mathrm{r}=0.892), \mathrm{Hg}(\mathrm{r}=0.738)$ and negative correlation $\mathrm{Ni}(\mathrm{r}=-0.754), \mathrm{Cd}(\mathrm{r}$ $=-798), \mathrm{Pb}(\mathrm{r}=-715), \mathrm{Ag}(\mathrm{r}=-0.521)$ and $\mathrm{Zn}(\mathrm{r}$ $=-0.822$ ) for the Kpeshie Lagoon, however none of the relationship was significant (at the 95\% significant level) (Tables 7\&8). For Muni Lagoon, Fe had a strong positive correlation with $\mathrm{Cu}(\mathrm{r}=0.999 ; \mathrm{p}<0.05), \mathrm{Ni}(\mathrm{r}$ $=0.992), \mathrm{Cr}(\mathrm{r}=0.874), \mathrm{Zn}(\mathrm{r}=0.871)$. None of the negative relation was strong. Mn for Kpeshie had a strong positive correlation with $\mathrm{Cr}(\mathrm{r}=0.935)$ and weak to moderate positive correlation with the rest of the metals, except $\mathrm{Hg}(\mathrm{r}=-0.035)$. However, there was a strong positive association between $\mathrm{Mn}$ and $\mathrm{Pb}, \mathrm{Hg}$, and $\mathrm{Zn}$ with $(\mathrm{r}=0.821,0.702$ and 0.751$)$ respectively for Muni Lagoon. Cu had a strong positive correlation with $\mathrm{Cr}(\mathrm{r}=0.732)$ and $\mathrm{Hg}$ $(\mathrm{r}=0.868)$ and negative correlation with $\mathrm{Ni}(\mathrm{r}$ $=-0.573), \mathrm{Cd}(\mathrm{r}=-0.564), \mathrm{Pb}(\mathrm{r}=-0.64)$ and $\mathrm{Zn}(\mathrm{r}=-0.643)$ for Kpeshie lagoon. However, for Muni lagoon, $\mathrm{Cu}$ had a strong positive relationship with $\mathrm{Ni}(\mathrm{r}=0.984), \mathrm{Cr}(0.846)$ and $\mathrm{Zn}(0.896)$, with weak to moderate association with $\mathrm{Cd}, \mathrm{Pb}$, and $\mathrm{Hg}$. The correlation between $\mathrm{Ni}$ and $\mathrm{Cd}(\mathrm{r}=0.987 ; \mathrm{p}<0.05), \mathrm{Pb}(\mathrm{r}=0.966$; $\mathrm{p}<0.05)$ and $\mathrm{Zn}(\mathrm{r}=0.994 ; \mathrm{p}<0.01)$ were strongly positive and significant with $\mathrm{Ag}(\mathrm{r}=$ 0.901 ) being positive but not significant in Kpeshie lagoon. There was strong negative relation with $\mathrm{Hg}(\mathrm{r}=-0.759)$. Ni however, has a strong correlation with $\mathrm{Cr}(\mathrm{r}=0.928), \mathrm{Zn}(\mathrm{r}$ $=0.802)$ and $\operatorname{Hg}(\mathrm{r}=-0.505)$ being negative in the Muni Lagoon. $\mathrm{Cr}$ had a strong correlation with $\mathrm{Pb}(\mathrm{r}=-0.703), \operatorname{Ag}(\mathrm{r}=0.623), \mathrm{Hg}(\mathrm{r}=$ $-0.827)$ and $\mathrm{Zn}(\mathrm{r}=0.522)$ in Muni but none of the relationship with these same metals in Kpeshie is strong. In Kpeshie, Cd has a strong association with $\mathrm{Pb}(\mathrm{r}=0.916), \mathrm{Ag}(\mathrm{r}=0.920)$, $\mathrm{Zn}(\mathrm{r}=0.991 ; \mathrm{p}<0.01)$ and $\mathrm{Hg}(\mathrm{r}=-0.606)$ whilst in Muni none of the association was significant with only Ag recording a positive relationship. $\mathrm{Cd}$ as a metal is not mined, but is 
usually a by-product of the smelting of other metals such as zinc, lead, and copper (Dinis and Fiuza, 2011). Hence, its strong association with $\mathrm{Pb}$ and zinc in the sediments of Kpeshie Lagoon, is indicative of coming from the same source. $\mathrm{Pb}$ had a strong relation with $\mathrm{Ag}, \mathrm{Hg}$ and $\mathrm{Zn}(\mathrm{r}=0.956 ; \mathrm{p}<0.05)$ which is significant in Kpeshie. This could be indicative of the enrichment of $\mathrm{Pb}$ and $\mathrm{Zn}$ coming from a common source. It also had a strong relation with $\mathrm{Ag}$ and $\mathrm{Hg}$ but not with $\mathrm{Zn}(\mathrm{r}=0.240)$ in the Muni. Ag had a strong positive relation with $\mathrm{Zn}$, and $\mathrm{Hg}$ had a strong but negative association with $\mathrm{Zn}$ in Kpeshie. For Muni, Ag had a strong negative relation with $\mathrm{Hg}$. This clearly shows that the $\mathrm{Hg}$ in Muni is not from a gold mining source since Au always have traces of Ag associated with it (GEUS, 2017).

\section{Conclusions}

The assessment of $\mathrm{Fe}, \mathrm{Mn}, \mathrm{Cu}, \mathrm{Ni}, \mathrm{Cr}, \mathrm{Cd}, \mathrm{Pb}$, $\mathrm{Ag}, \mathrm{Hg}$ and $\mathrm{Zn}$ did not show any statically clear difference in the mean concentrations of the Kpeshie and Muni Lagoons in a exception of $\mathrm{Mn}$ which was statistically significant, with Muni being higher than Kpeshie comparatively. Kpeshie Lagoon recorded enrichment for $\mathrm{Cd}, \mathrm{Pb}, \mathrm{Ag}, \mathrm{Hg}$ and $\mathrm{Zn}$ which is indicative of anthropogenic influence, whilst Muni recorded $\mathrm{Cd}, \mathrm{Mn}, \mathrm{Ag}, \mathrm{Hg}$ and $\mathrm{Zn}$ as metals of anthropogenic influence with $\mathrm{Mn}$ replacing $\mathrm{Pb}$, even though station $\mathrm{MM}$ recorded some $\mathrm{Pb}$ enrichment in the scenario. $\mathrm{Pb}$ is the dominant metal pollutant in all the stations except one in Kpeshie, with Muni recording enrichment with $\mathrm{Pb}$ in station $\mathrm{MM}$ only. Hence $\mathrm{Pb}$ could be said to be the major pollutant associated with an urbanized zone such as Kpeshie Lagoon and therefore made the Kpeshie Lagoon more polluted with respect to $\mathrm{Pb}$ enrichment. Pearson correlation matrix also shows that $\mathrm{Pb}$ had a strong relation with two of the most enriched metals, $\mathrm{Ag}$ and $\mathrm{Hg}$, as well as $\mathrm{Zn}(\mathrm{r}=0.956 ; \mathrm{p}<0.05)$, which was significant in Kpeshie which indicates that they might be coming from a common source, possibly industries. It also had a strong association with $\mathrm{Ag}$ and $\mathrm{Hg}$ but not with $\mathrm{Zn}(\mathrm{r}$ $=0.240$ ) in Muni. The assessment also shows that $\mathrm{Ag}$ and $\mathrm{Hg}$ are the most enriched metals in the sediments of the two lagoons and should be closely monitored.

\section{References}

Addo, M. A, Okley, G. M, Affum, H. A, Acquah, S., Gbadago, J. K., Senu, J. K. \& Botwe, B. O. (2011) Water quality and level of some heavy metals in water and sediments of Kpeshie lagoon, La-Accra, Ghana. Res J Environ Earth Sci 3 (5), 487 - 497.

APHA (2017) "Standard Method for the Examination of Water and Wastewater," 23th Edition, American Public Health Association, Washington D.C.

ATSDR (1990) Toxicological profile for silver. Atlanta, GA, US Department of Health and Human Services, Public Health Service, Agency for Toxic Substances and Disease Registry (TP-9024).

Benhaddya, M. L. \& HAdjel, M. (2013) Spatial distribution and contamination assessment of heavy metals in surface soils of Hassi Messaoud, Algeria. Environ. Earth Sci.71 (3), 1473 - 1486.

BIRCH, G. F. (2003) A test of normalization methods for marine sediment, including a new post extraction normalization technique. Hydrobiologia 492, $5-13$.

DASKAlakis, K. D. \& O'CONNOR, T. P. (1995) Normalization and elemental sedimentcontamination in the Coastal United States. Environmental Science and Technology 29, $470-477$.

Dinis, M. \& FiUZA, A. (2011) Exposure assessment to heavy metals in the Environment: measures 
to eliminate or reduce the exposure to critical receptors. Geo-Environment and Resources Research Center (CIGAR), Faculty of Engineering, University of Porto, Rua Dr. Roberto Frias, 4200465, Porto, Portugal.

Esen, E., KüÇüKsezgin, F. \& Uluturhan, E. (2010) Assessment of trace metal pollution in surface sediments of Nemrut Bay, Aegean Sea. Environmental Monitoring and Assessment 160, 257 - 266. doi: 10.1007/s10661-008-0692-9.

Fianko, R., Larr, C., Osei, J., Anim, K. A., Gibrilla, A. \& Adomako, D. (2013) Evaluation of some heavy metal loading in the Kpeshie lagoon, Ghana. Appl Water Sci Springer Int. 3, 311 - 319.

Francis, C. W. \& White, G. H. (1987) Leaching of toxic metals from incinerator ashes. $J$ Water Pollut Control Fed 59, 979 - 986.

GEOLOGICAL SURVEY OF DENMARK AND GREENLAND (2017) Artisanal and Smallscale mining Handbook for Ghana. The Danish Ministry of Energy, Utilities and Climate. Copenhagan, Denmark.

Guentzel, J., Landing, W., Gill, G. \& Pollman, C. (2001) Processes influencing rain fall deposition of mercury in Florida. Environ Sci Technol. 35, $863-73$.

Hutton, M., Chaney, R. L., Krishna, C. R., Murti, M., Olade, A. \& Page, A. L.(1987) Group Report. In:Hutchson, T.C. and K.M. Meena, (Eds.), Lead, Mercury, Cadmium and Arsenic in the Environment.John Wiley, New York, pp: $35-41$.

Jensen, A. \& Iverfeldt, A. (1994) Atmospheric bulk deposition of mercury to thesouthern Baltic Sea area. In: Huckabee J, Watras C, editors. Mercurypollution: integration and synthesis. Boca Raton, FL.: Lewis Publishers; p. 221 - 9.

Kingston, H. M. \& Walter, P. J. (1992) Comparison of Microwave versus Conventional Dissolution for Environmental Applications. Spectroscopy 7 (9), 20 - 27.
KJerfve, B. (1994) Coastal Lagoons. in Coastal Lagoon Processes B. Kjerfve (ed.). ElsevierOceanography Series, 60. Pp $1-8$.

LaAR, C., BAm EpK, O.s., Anima, O. J., Bimi. L., Ganyaglo, S. Y., Gibrilla, A. \& Adomako, D. (2011) Effect of anthropogenic activities on an ecologically important wetland in Ghana. Journal of Biodiversity and Environmental Sciences $1(6), 9-21$.

Long, E. R., Macdonald, D. D., Smith, S. L. \& CAlder, F. D. (1995) Incidence of adverse biological effects within ranges of chemical concentrations in marine and estuarine sediments. Environmental Management 19, 18 - 97.

Nowrouzi, M. \& Pourkhabbaz, A. (2014) Application of geoaccumulation index and enrichmentfactor for assessing metal contamination in thesediments of Hara Biosphere Reserve, Iran. Chemical Speciation and Bioavailability, 26 (2).

Ntimoah-Baidoo, Y. \& Gordon, C. (1991) Coastal Wetlands Management Plans: Ghana. A Report Prepared for The World Bank and The Environmental Protection Council, Ghana. No. 51166.

Remor, M. B., Sampaio, S. C., Derijk, S., Boas, M. A.v., Gotardo, J. T., Pinto, E. T. \& ScharDONG, F. A. (2018) Sediment geochemistry of the urban Lake Paulo Gorski. Int. J. Sediment Res. 33, $406-414$.

SAlomons, W. \& Forstner, U. (1984) metals in the hydropsyche: berlin, springer-verlag, 349 p.

SANDERs, J., Riedel, G. \& AbBe, G. (1991) Factors controlling the spatialand temporal variability of trace metal concentrations in Crassostreavirginica(Gmelin). In: Elliot M, Ducrotoy J, eds. Estuaries andcoasts: spatial and temporal intercomparisons. Proceedings of the Estuarine and Coastal Sciences Association Symposium, 4-8 September 1989, University of Caen, France. 
Simex, S. A. \& Helz, G. R. (1981) Regional geochemistry of traceelements in Checapeake Bay. Environ. Geol. 3 (6), 315 - 323.

Superville, P - J., Prygiel, E., Magnier, A., Lesven, L., Gao, Y., Baeyens, W. (2014) Daily variations of $\mathrm{Zn}$ and $\mathrm{Pb}$ concentrations in the Deûle River in relation to the resuspension of heavily polluted sediments. Sci Total Environ. $470-471,600-7$.

Tay, C., Asmah, R. \& Biney, C. A. (2010) A comparative study of the pollution status of Sakumono II and Muni Lagoons in Ghana. Water Science and Technology 62.5, 1067 - 1075.
Turekian, K. K. \& Wedepohl, K. H. (1961) Distribution of the elements in some major units of the earth's crust. Geol. Soc. Am.Boll. 72, 175 - 192.

USEPA (1980) Ambient water quality criteria for silver. Washington, DC, US Environmental Protection Agency (440/5-80-071).

Windom, H. L., Schropp, S. J., Calder, F. D., Ryan, J. D., Smith, R. G., Burney, L.C., Lewis, F. G. \& Rawlinson, C. H. (1989) Natural trace metal concentrations in estuarine and coastal marine sediments of the Southeastern United States. Environmental Science and Technology 23, $314 \mathrm{e} 320$.

Received 08 Jul 20; revised 12 Jul 21. 